\title{
In vitro comparative study on the relevance of dental radiographies in detection of dental caries
}

\author{
Studiu comparativ in vitro privind relevanţa radiografiilor dentare în detectarea \\ leziunilor carioase
}
Cornelia Bîcleşanu, Anamaria Florescu, Alexandru Burcea, Laur lacob, Ştefan Țigăeru Polihroniade, Denisa Danilă
Facultatea de Medicină Dentară, Universitatea „Titu Maiorescu“, Bucureşti

\begin{abstract}
Radiography is the most used complementary means to diagnose dental caries.

The aim of this study is to verify the expertise in radiography interpretation of a group of clinicians with different experience and training and also of a group of last year dental medicine students.

Material and method. For this study, 18 extracted teeth were used on which proximal and occlusal deminerali-zation, enamel preparations and dentin preparations were conducted. The teeth surfaces were then isolated with a nail polish except the preparations. Teeth were mounted in acrylic arcades and retro-alveolar radiographs, bite-wing radiographs and $\mathrm{CBCT}$ were performed. A questionnaire was developed that was sent online to the groups of dental clinicians and students.

Results and discussion. Retroalveolar radiographs, proximal preparations: $49 \%$ of respondents did not diagnose demineralization, $42 \%$ caries in enamel and $16 \%$ caries in dentin. Oclusal preparations: $88 \%$ of the respondents did not diagnose demineralization, $60 \%$ of the caries in the enamel, all the respondents diagnosed the caries in the dentine. Bitewing radiographs, proximal preparations: $2 \%$ of respondents did not diagnose demineralization, $12 \%$ caries in enamel and $2 \%$ caries in dentin. Occlusal preparations: $90 \%$ of the respondents did not diagnose demineralization, $26 \%$ caries in enamel, all diagnosed caries in the dentine. At CBCT, proximal preparations: $26 \%$ of respondents did not diagnose demineralization, $26 \%$ caries in enamel and $20 \%$ caries in dentin. At the occlusal level, $22 \%$ of respondents did not diagnose demineralization, $8 \%$ caries in enamel and $8 \%$ caries in dentin.

Conclusions. Following the radiological examinations conducted in this study, we can say that dental caries are diagnosed most quickly and correctly when they affect both the analyzed proximal and occlusal surfaces with evolution in dentin.
\end{abstract}

Keywords: demineralization, incipient caries, periapical X-rays, bitewing X-rays,

Cone Beam Computer Tomography (CBCT)

\section{REZUMAT}

Radiografia reprezintă unul dintre cele mai uzuale mijloace complementare pentru diagnosticarea cariei dentare.

Scopul acestui studiu este să verifice expertiza unui grup de clinicieni cu experienţă şi pregătire diferite, precum şi a unor studenţi la Facultatea de Medicină Dentară în ani terminali în interpretarea Rx pentru detectarea cariei dentare.

Material şi metodă. Studiul s-a efectuat pe 18 dinţi extraşi pe care s-au efectuat preparaţii proximale şi ocluzale, care au constat în demineralizare, cavităţi în smalţ şi în dentină. Suprafeţele dinţilor au fost apoi izolate cu lac de unghii, mai puţin preparaţiile realizate. Dinţii au fost montaţi în arcade didactice de acrilat şi au fost realizate radiografii retroalveolare, bitewing şi CBCT. S-a conceput un chestionar care a fost trimis online unui grup de clinicieni şi studenţi la Medicină Dentară.

Rezultate şi discuţii. Radiografia retroalveolară, la nivel proximal: 49\% dintre repondenţi nu au diagnosticat demineralizare, $42 \%$ caria în smalţ şi $16 \%$ caria în dentină. La nivel ocluzal: $88 \%$ dintre repondenţi nu au diagnosticat demineralizare, $60 \%$ caria în smalţ, toţi repondenţii au diagnosticat caria în dentină. Radiografia bitewing, proximal: $42 \%$ dintre repondenţi nu au diagnosticat demineralizare, $12 \%$ caria în smalţ şi $2 \%$ caria în dentină. Ocluzal, $90 \%$ din repondenţi nu au diagnosticat demineralizare, $26 \%$ caria în smalţ, toţi caria în dentină. La CBCT, proximal: $26 \%$ dintre repondenţi nu au diagnosticat demineralizarea, $26 \%$ caria în smalţ şi $20 \%$ caria în dentină. La nivel ocluzal, $22 \%$ dintre repondenţi nu au diagnosticat demineralizare, $8 \%$ caria în smalţ şi $8 \%$ caria în dentină.

Concluzii. În urma examinărilor radiologice realizate în acest studiu, putem aprecia că detectarea cariei dentare este diagnosticată cel mai repede şi corect atunci când interesează ambele suprafeţe analizate, proximală şi ocluzală, cu evoluţie în stratul dentinar.

Cuvinte cheie: demineralizare, carie incipientă, radiografie retroalveolară, radiografie cu film muşcat (bitewing), tomografie computerizată cu fascicul conic (CBCT) 


\section{INTRODUCERE}

Metoda esenţiala de prevenire a cariei dentare este reprezentată de aplicarea unei igiene dentare corecte, a unei diete cu consum limitat de zaharuri şi, nu în ultimul rând, monitorizare permanentă prin controale periodice la cabinetul dentar. În felul acesta se pot depista precoce leziunile carioase incipiente astfel încât remanenţa dintelui pe arcadă să fie mult prelungită.

Decizia de a restaura dinţii este una importantă, deoarece este adesea începutul unui ciclu nefericit de înlocuire a restaurării în anii următori cu altele progresiv mai mari, ducând în cele din urmă la o restaurare masivă ce poate determina fractura, urmată de extracţie. Abordările care întârzie plasarea primei restaurări pot fi o sursă esenţială de îmbunătăţire a eficacităţii pe termen lung a îngrijirii dentare şi, prin urmare, a calităţii acesteia (1).

Diagnosticul precoce şi corect al cariei este esenţial pentru a putea institui un tratament adecvat, corelat cu particularităţile clinice ale fiecărui pacient în parte. Detectarea în faze incipiente a cariei dentare ar trebui să fie scopul primordial al fiecărui clinician.

De asemenea, asocierea examinării clinice cu o radiografie dentară convenţională, de cele mai multe ori, nu mai reprezintă o opţiune viabilă pentru diagnosticarea cariei incipiente sau a demineralizarilor.

În aceste condiţii, au apărut noi metode de investigaţie, reprezentate de radiografia digitală, metoda laser fluorescenţă, tomografia computerizată (CT) şi, mai nou, CBCT, ultimele două fiind metode rar folosite totuşi pentru diagnosticarea cariilor, datorită nivelului de radiaţie ridicat dar şi costului ridicat.

Studiile arată că sistemul CBCT este superior în determinarea profunzimii cariilor comparativ cu radiografia convenţională. De menţionat că majoritatea studiilor sunt realizate pe localizările exclusiv proximale ale proceselor carioase şi mai puţine se referă la cariile situate pe suprafaţa ocluzală (2-8).

Scopul acestui studiu este să compare in vitro perfomanţele radiografiei bitewing, radiografiei retroalveolare şi CBCT în evidenţierea şi determinarea profunzimii cariilor dentare. Obiectivul este reprezentat de realizarea comparaţiei între sensibilitatea fiecărei metode de investigare propuse şi cuantificarea capacităţii de interpretare a acestor radiografii de către diverse categorii de clinicieni.

\section{MATERIAL ŞI METODĂ}

Studiul a fost realizat pe un lot de 18 molari şi premolari indemni, extraşi din motive ortodontice / parodontale / chirurgicale. Până la realizarea experimentului, dinţii au fost stocaţi în ser fiziologic.

Cercetarea s-a realizat dupa obţinerea consimţământului pacienţilor pentru utilizarea dinţilor pentru experimente de cercetare.

Dinţii au fost împărţiţi în 6 loturi a câte 3 dinţi fiecare, care au fost supuse următoarelor preparaţii:

Lot 1 - dinţii au fost supuşi unui proces de demineralizare: pe faţa proximală a fost izolată o suprafaţă de aproximativ $2 \mathrm{~mm}$ care a fost demineralizată;

Lot 2 - pe una dintre suprafeţele proximale ale dinţilor au fost realizate preparaţii tip casetă cu localizare la nivelul smalţului;

Lot 3 - pe una dintre suprafeţele proximale ale dinţilor au fost realizate preparaţii tip casetă cu localizare la nivelul smalţului şi dentinei;

Lot 4 - dinţii au fost supuşi unui proces de demineralizare pe faţa ocluzală;

Lot 5 - preparare cavitate ocluzală la nivelul smalţului;

Lot 6 - preparare cavitate ocluzală la nivelul smalţului şi dentinei.

Pentru determinarea adâncimii preparaţiilor s-a folosit sonda parodontală, care are pe partea activă gradaţii din $\mathrm{mm}$ în $\mathrm{mm}$. Preparaţiile în smalţ au fost realizate la $1,5 \mathrm{~mm}$, iar cele în dentină la $3 \mathrm{~mm}$. Suprafeţele dentare au fost apoi izolate cu lac de unghii, mai putin zonele preparate (fig. 1-3). Dinţii au fost apoi introduşi în soluţie de acid acetic $(\mathrm{pH}=3,5)$ timp de 1,3,5 zile, în recipiente separate. După această perioadă, cele şase grupuri de dinţi au fost montate în arcade artificiale ale modelelor didactice din material plastic, până la un nivel JSC şi, pe cât posibil, să simuleze contactul interdentar real; montarea dinţilor s-a făcut cu suprafaţa preparată în contact cu suprafaţa indemnă a dintelui vecin pentru preparaţiile proximale, apoi au fost realizate radiografii retroalveolare, RBW, CBTC (fig. 4).

Radiografiile bitewing au fost obţinute prin proiectarea fasciculului pe direcţie vestibulo-orală, tangenţial la supraţetele proximale, distanţa obiect- 
film fiind de aprox $0,5 \mathrm{~cm}$. Timpul de expunere de $0,2 \mathrm{sec}, \mathrm{kV} 60, \mathrm{~mA} 7$.

Pentru radiografiile retroalveolare timpul de expunere a fost de $0,2 \mathrm{~s}, \mathrm{kV} 60, \mathrm{~mA} 7$.

\section{Lot 1 - Prepararea fețelor distale}
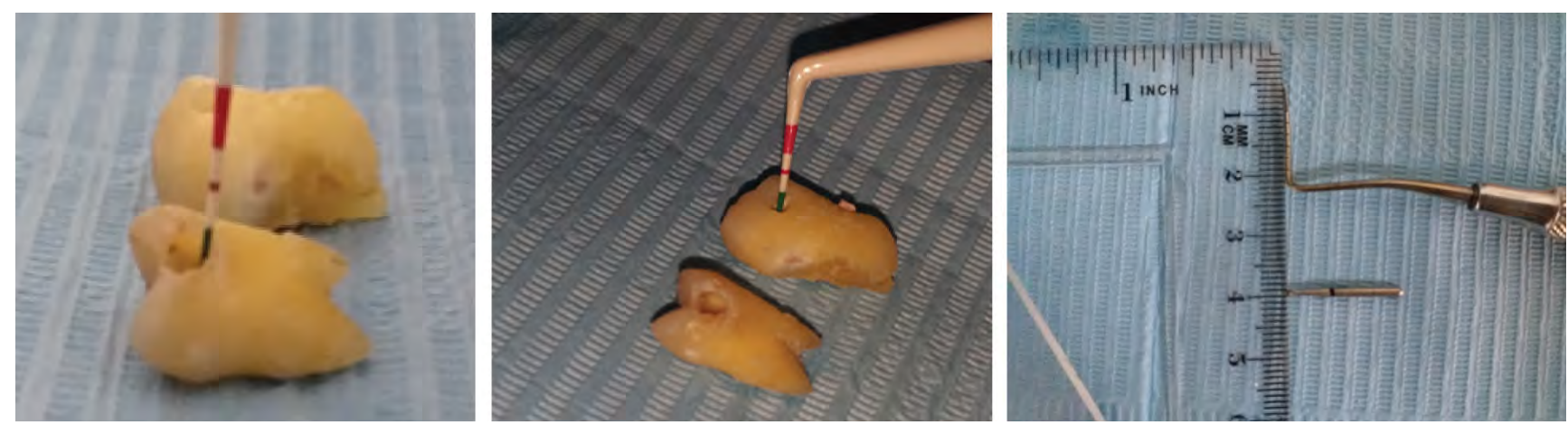

FIGURA 1. Măsurarea şi determinarea adâncimii cavităților
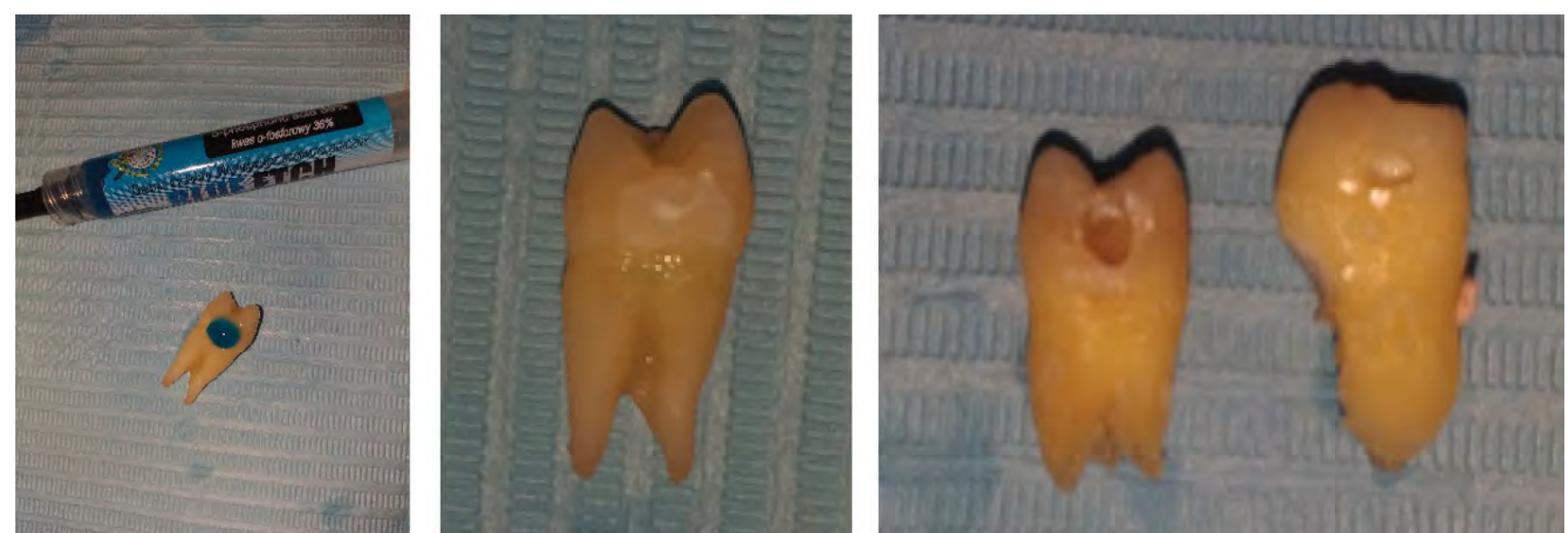

FIGURA 2. Cavități în smalț şi dentină pe fețele distale

\section{Lot 2 - Prepararea fețelor ocluzale}
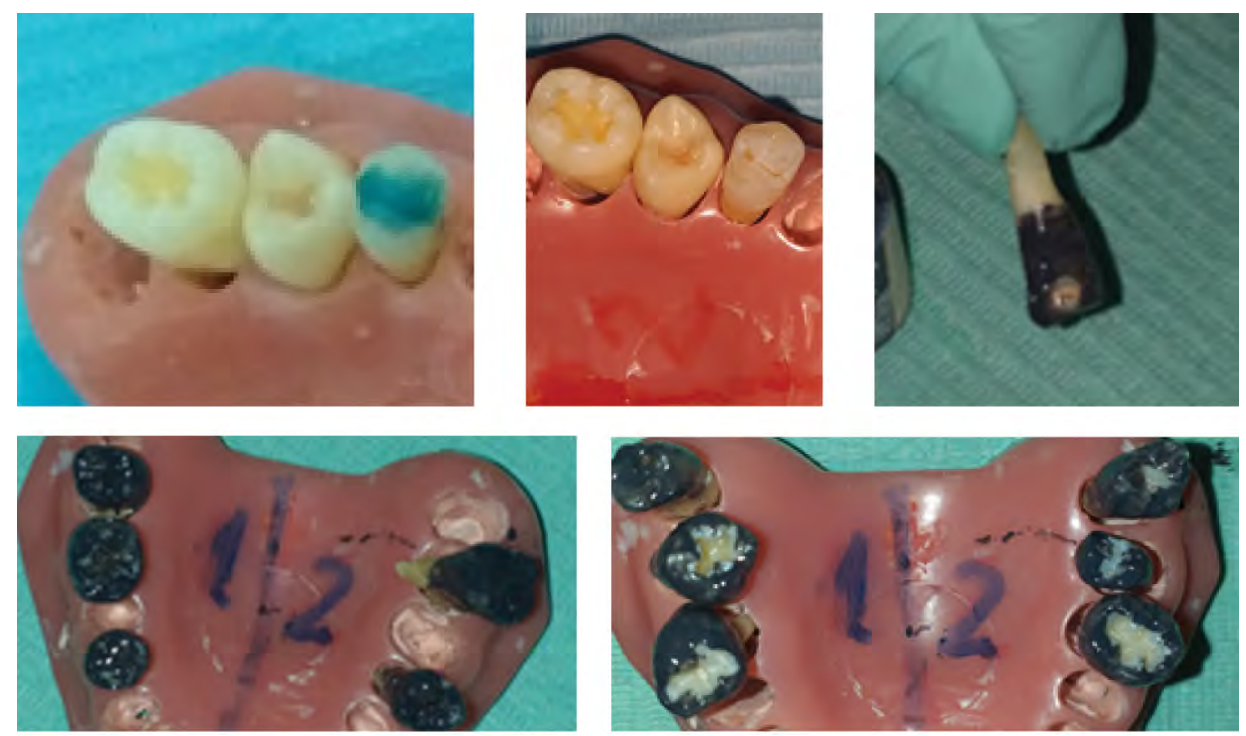

FIGURA 3. Cavități pe fețele ocluzale, dinți preparați pentru $R x$ 


\section{Dintiextrati}

\section{$a=18$}
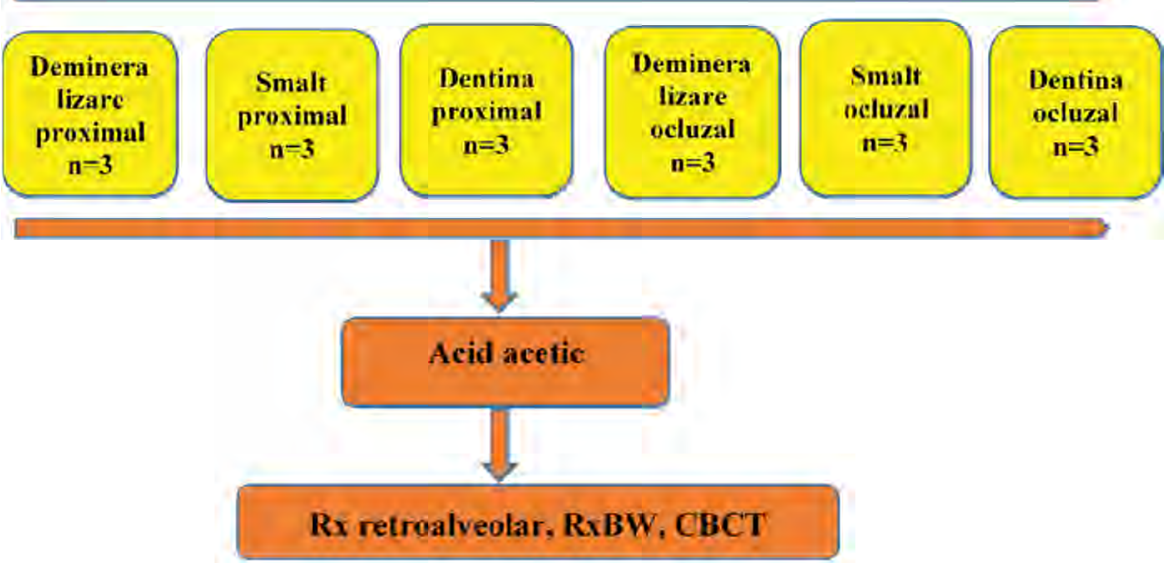

FIGURA 4. Schema protocolului de cercetare

Radiografiile au fost apoi trimise online, pentru interpretare, în cadrul unui chestionar, unor categorii diferite de practicieni: medici dentişti (absol- venţi ultimii 5 ani), medici specialişti, medici primari şi studenţi an 6 .

\section{CHESTIONAR}

\section{Distribuţia pe sexe}

$\square$ Masculin $\square$ Feminin

\section{Din ce categorie de vârstă faceţi parte?}
$\square$ 26-36 ani
$\square$ 37-46 ani
$\square$ 47-56 ani
$\square$ 57-66 ani

\section{Vechime activitate}
$\square$ 1-3 ani
$\square$ 3-10 ani
$\square$ peste 10 ani

\section{Categorie de calificare}

$\square$ medic dentist

$\square$ medic specialist

$\square$ medic primar

$\square$ student an 6 Facultatea de Medicină Dentară

\section{Cât de des utilizaţi RX pentru detectarea cariei dentare?}

$\square$ des $\square$ foarte des $\square$ rar

6. Vă rugăm să interpretaţi RX alăturate și să ordonaţi grupurile de Rx în funcţie de interpretarea personală 


\begin{tabular}{|l|l|l|}
\hline \multicolumn{3}{|c|}{ Lot 1 carii distale } \\
\hline \multicolumn{1}{|c|}{ Rx retroalv. } & \multicolumn{1}{c|}{ BW } & CBCT \\
\hline$\square$ demineralizare & $\square$ demineralizare & $\square$ demineralizare \\
\hline$\square$ carie smalț & $\square$ carie smalț & $\square$ carie smalț \\
\hline$\square$ carie smalț şi dentină & $\square$ carie smalț şi dentină & $\square$ carie smalț şi dentină \\
\hline
\end{tabular}

\begin{tabular}{|l|l|l|}
\hline \multicolumn{3}{|c|}{ Lot 2 carii ocluzale } \\
\hline \multicolumn{1}{|c|}{ Rx retroalv. } & \multicolumn{1}{c|}{ BW } & CBCT \\
\hline$\square$ demineralizare & $\square$ demineralizare & $\square$ demineralizare \\
\hline$\square$ carie smalț & $\square$ carie smalț & $\square$ carie smalț \\
\hline$\square$ carie smalț şi dentină & $\square$ carie smalț şi dentină & $\square$ carie smalț şi dentină \\
\hline
\end{tabular}

\section{VĂ MULŢUMESC PENTRU COLABORARE!}

\section{REZULTATE}

$\mathrm{Au}$ fost trimise un număr de 75 de chestionare, din care au fost returnate 50 , rata de răspuns fiind de 48,2\%. Lotul a fost împărţit, în funcţie de vârstă, în 4 grupe: 26-36 ani, 37-46 ani, 47-56 ani, peste 56 ani (fig. 5).

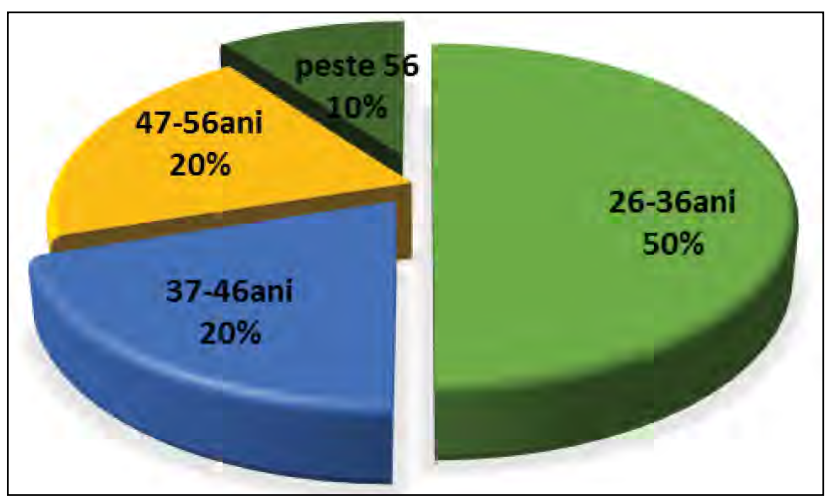

FIGURA 5. Repartiție lot pe vârstă

$50 \%$ dintre repondenţi sunt încadraţi în categoria de vârstă 26-36 ani şi doar $10 \%$ au peste 56 ani.

Repartiţia repondenţilor după nivelul de pregătire este prezentată în fig. 6 .

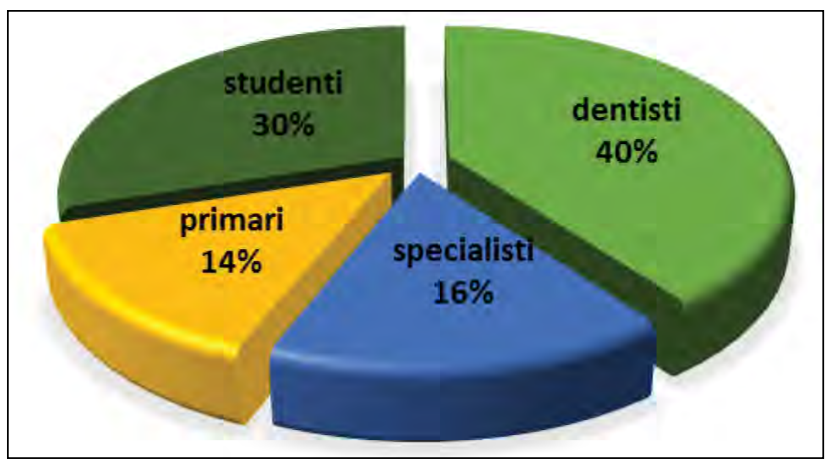

FIGURA 6. Repartiție lot după pregătire
Se constată că dentiştii reprezintă aproximativ jumatate din lot, urmat de lotul studenţilor în ani terminali, care reprezintă aproximativ $1 / 3$ din lot $(30 \%)$, restul fiind reprezentat în mod aproape egal, $16 \%$ medici specialişti, respectiv $14 \%$ medici primari.

Repartiţia repondenţilor pe sexe şi nivelul de pregătire este prezentată în fig. 7 .

Se constată că la toate categoriile sexul feminin este predominat procentual la toate categoriile analizate.

Repartiţia pe vârstă şi nivel pregătire a lotului analizat arată că medicii dentişti au reprezentarea majoritară în categoriile de vârstă 26-36 ani şi 3746 ani, iar în categoria peste 56 ani sunt prioritari medici primari. De asemenea, se evidenţiază faptul că nu există studenţi peste vârsta de 36 ani (fig. 8).

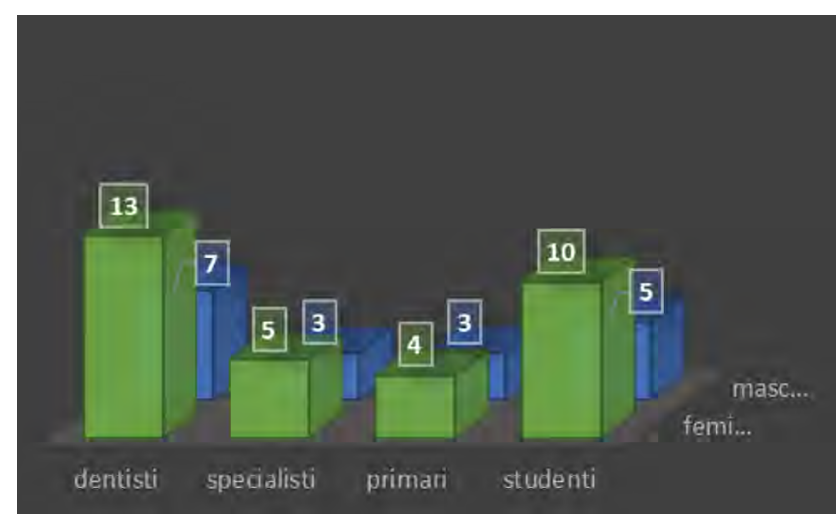

FIGURA 7. Repartiția pe sexe şi nivel pregătire 


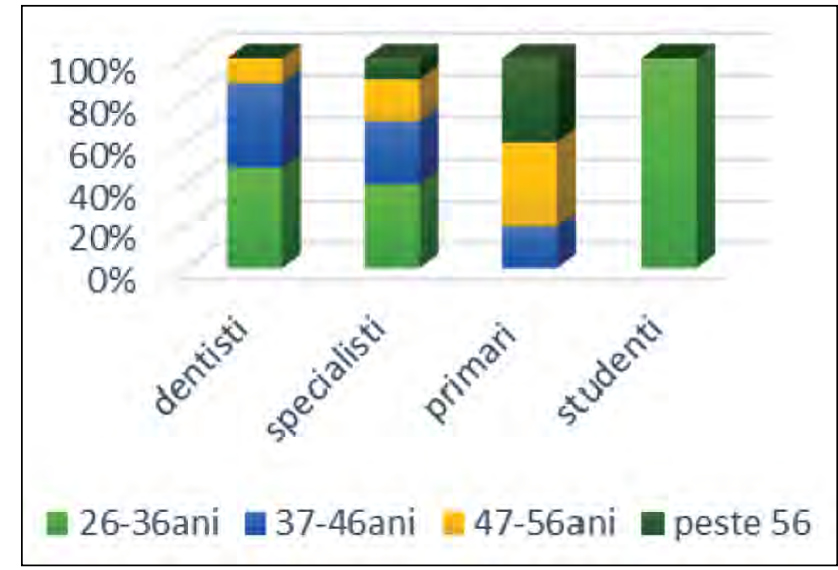

FIGURA 8. Repartitia pe vârstă şi nivel pregătire

Pentru a demonstra în ce măsură repondenţii utilizează radiografiile ca metodă de diagnostic sau evaluare, am realizat repartiţia lor după nivelul de pregătire şi gradul de utilizare a Rx (fig. 9).

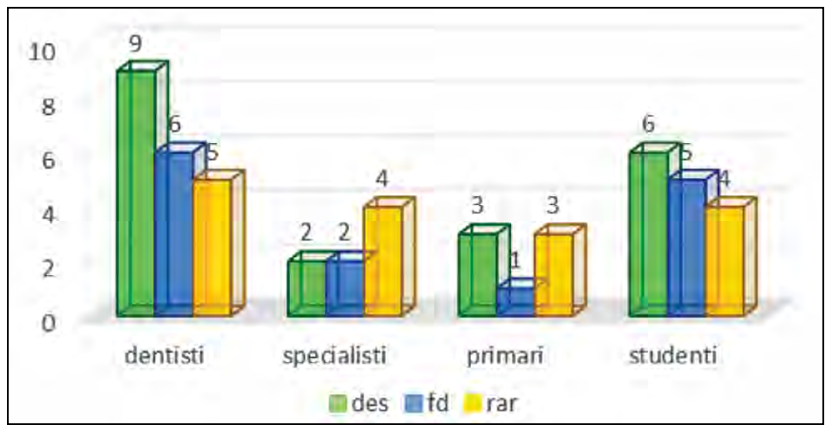

FIGURA 9. Repartiție lot după nivel şi utilizare $R x$
Se poate observa că $12 \%$ dintre medicii dentişti utilizează foarte des radiografia dentară, în timp ce $8 \%$ dintre studenţi o folosesc foarte rar.

Din analiza efectuată pentru a vedea care dintre cele două sexe sunt mai interesate de recomandarea radiografiilor dentare, a rezultat că la toate categoriile de pregătire predomină sexul feminin (fig. 10).

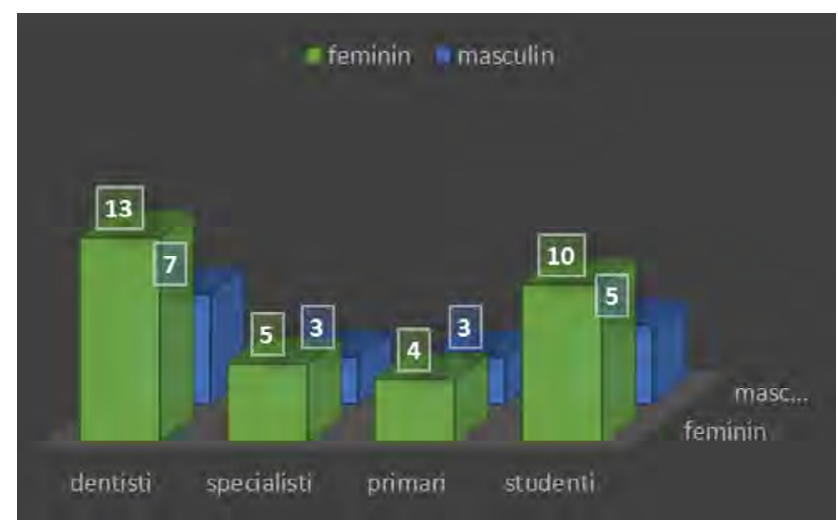

FIGURA 10. Repartiția sexe şi grad de utilizare $R x$

\section{Examen radiologic}

1. Radiografii retro-alveolare - Proximal (distal) (fig. 11)

2. Radiografii retro-alveolare - Ocluzal (fig. 12)

3. Radiografii bitewing - Proximal (fig. 13)

4. Radiografii bitewing - Ocluzal (fig. 14)
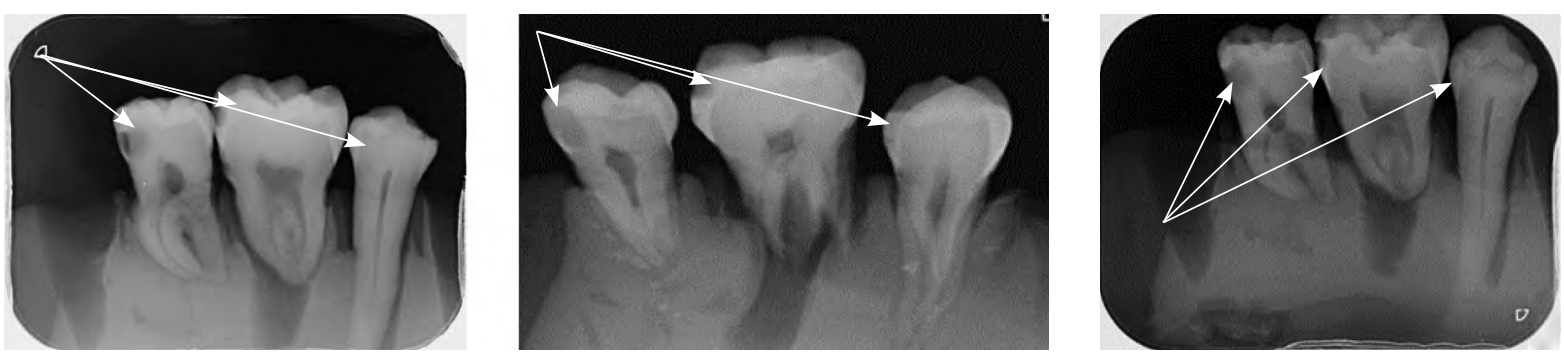

FIGURA 11. Demineralizare distală, 26 cavitate distală în smalț; 27 cavitate distală în dentină
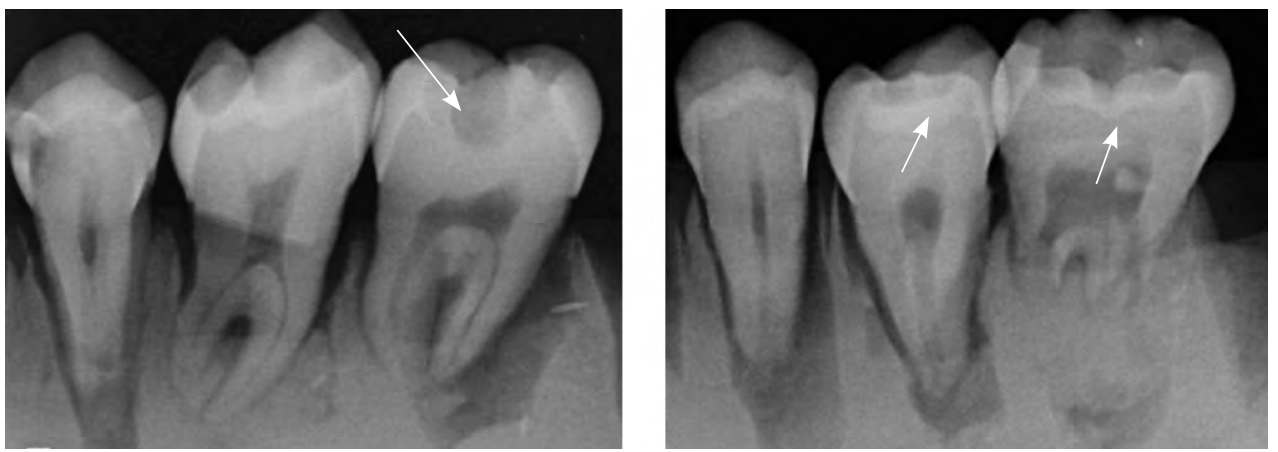

FIGURA 12. Carie mezială; nu se observă demineralizarea ocluzală; 26 cavitate ocluzală realizată în smalț /demineralizarea; 27 cavitate ocluzală în smalț şi dentină 

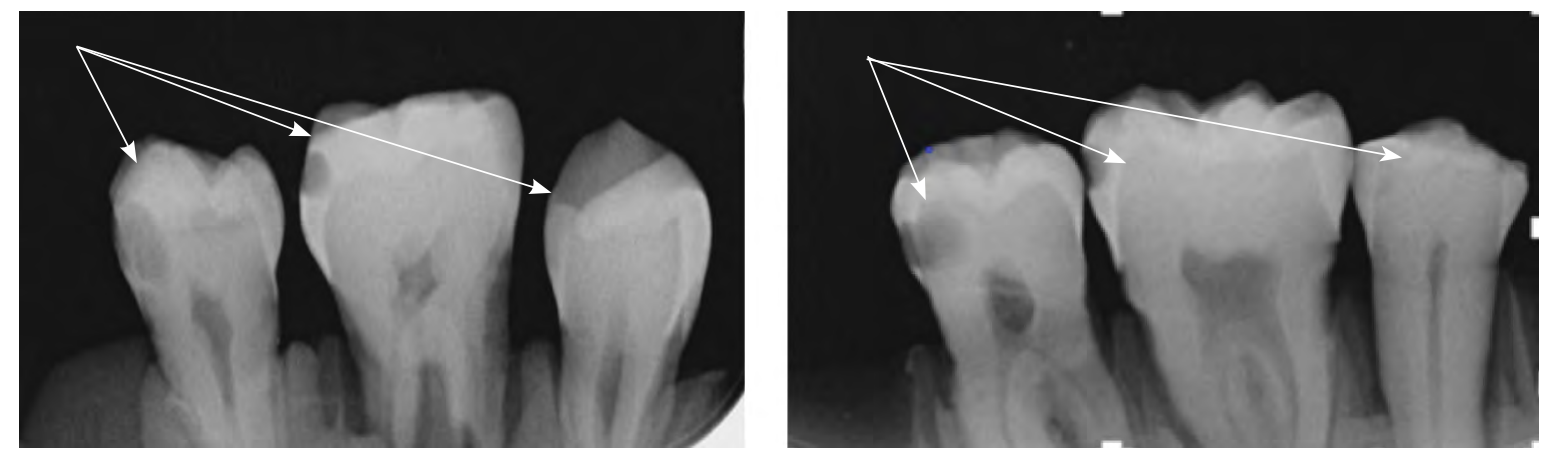

FIGURA 13. 15 demineralizare distală, 16 cavitate distală în smalț; 17 cavitate distală în smalț şi dentină
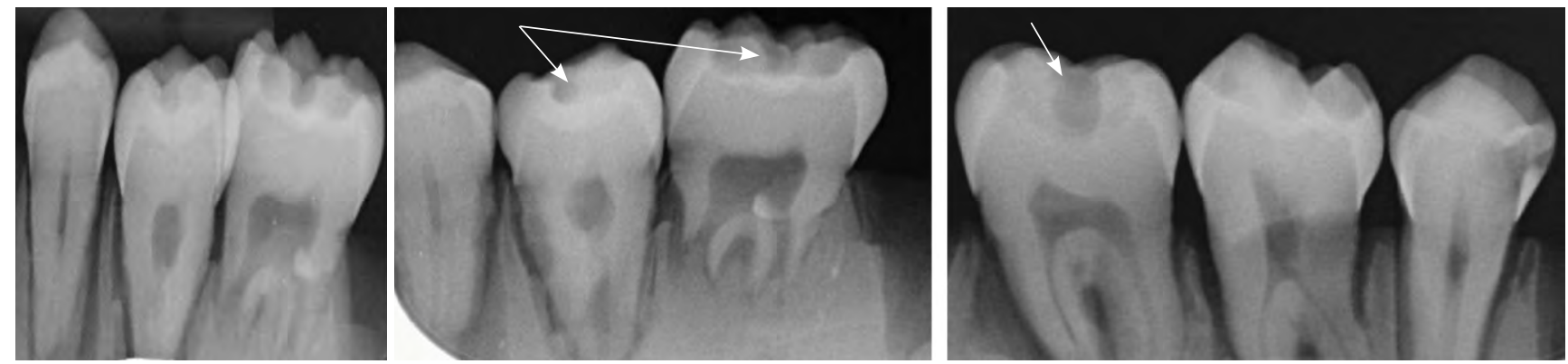

FIGURA14. 25 nu se observă demineralizarea ocluzală; 26 se observă cavitatea ocluzală realizată în smalț / demineralizarea; 27 cavitate ocluzală în smalț şi dentină

5. CBCT proximal - Diferite secţiuni, feţele proximale (fig. 15)

6. CBCT ocluzal - Diferite secţiuni, feţele ocluzale CBCT (fig. 16)

\section{Repartiția după recunoaşterea diagnosticului}

Radiografia retroalveolară, la nivel proximal: 49\% dintre repondenţi nu au diagnosticat demineralizare, $42 \%$ caria în smalţ şi $16 \%$ caria ocluzală în dentină.

La nivel ocluzal, 88\% dintre repondenţi nu au diagnosticat demineralizare, $60 \%$ caria în smalţ, toti repondenţii au diagnosticat caria în dentină (fig. 17).

Radiografia bitewing, la nivel proximal: $42 \%$ dintre repondenţi nu au diagnosticat demineralizare, $12 \%$ caria în smalţ şi $2 \%$ caria în dentină. Puţin peste jumătate dintre repondenţi cataloghează demineralizările şi cariile caria în smalţ drept dinţi indemni.

La nivel ocluzal, 90\% dintre repondenţi nu au diagnosticat demineralizare, $26 \%$ caria în smalţ şi toţi caria în dentină (fig. 18).

La CBCT, la nivel proximal: $26 \%$ dintre repondenţi nu au diagnosticat demineralizare, $26 \%$ caria în smalţ şi $20 \%$ caria în dentină.
La nivel ocluzal, 22\% dintre repondenţi nu au diagnosticat demineralizare, $8 \%$ caria în smalţ şi $8 \%$ caria în dentină (fig. 19).

\section{DISCUṬII}

Examinarea şi detectarea leziunilor carioase a fost în mod tradiţional limitată la criterii fizice cum ar fi dimensiunea, adâncimea şi prezenţa sau absenţa cavitaţiei. Dar detectarea nu este suficientă, ea trebuie asociată cu evaluarea activităţii leziunii cariilor şi, astfel, împreună pot concura la diagnosticarea cariei şi la stabilirea unui tratament adecvat. În plus, evaluarea celorlalţi factori etiologici ai cariei - respectiv igiena orală, numărul de microorganisme cariogene din placă şi salivă, utilizarea fluorurilor, aportul de zahăr, precum şi unele aspecte socio-economice precum venitul familiei şi nivelul de educaţie al părinţilor - aduce elemente esenţiale pentru a încadra pacientul într-o grupă de risc cariogen pentru a i se institui un tratament individualizat.

Din păcate, o observaţie a unei revizuiri a datelor a fost că metodele clinice de investigaţie a cariei dentare au avut tendinţa de a fi mai specifice decât sensibile (utilizarea lor are ca rezultat rezultate mai puţin fals negative decât constatările fals pozitive) (9). De 

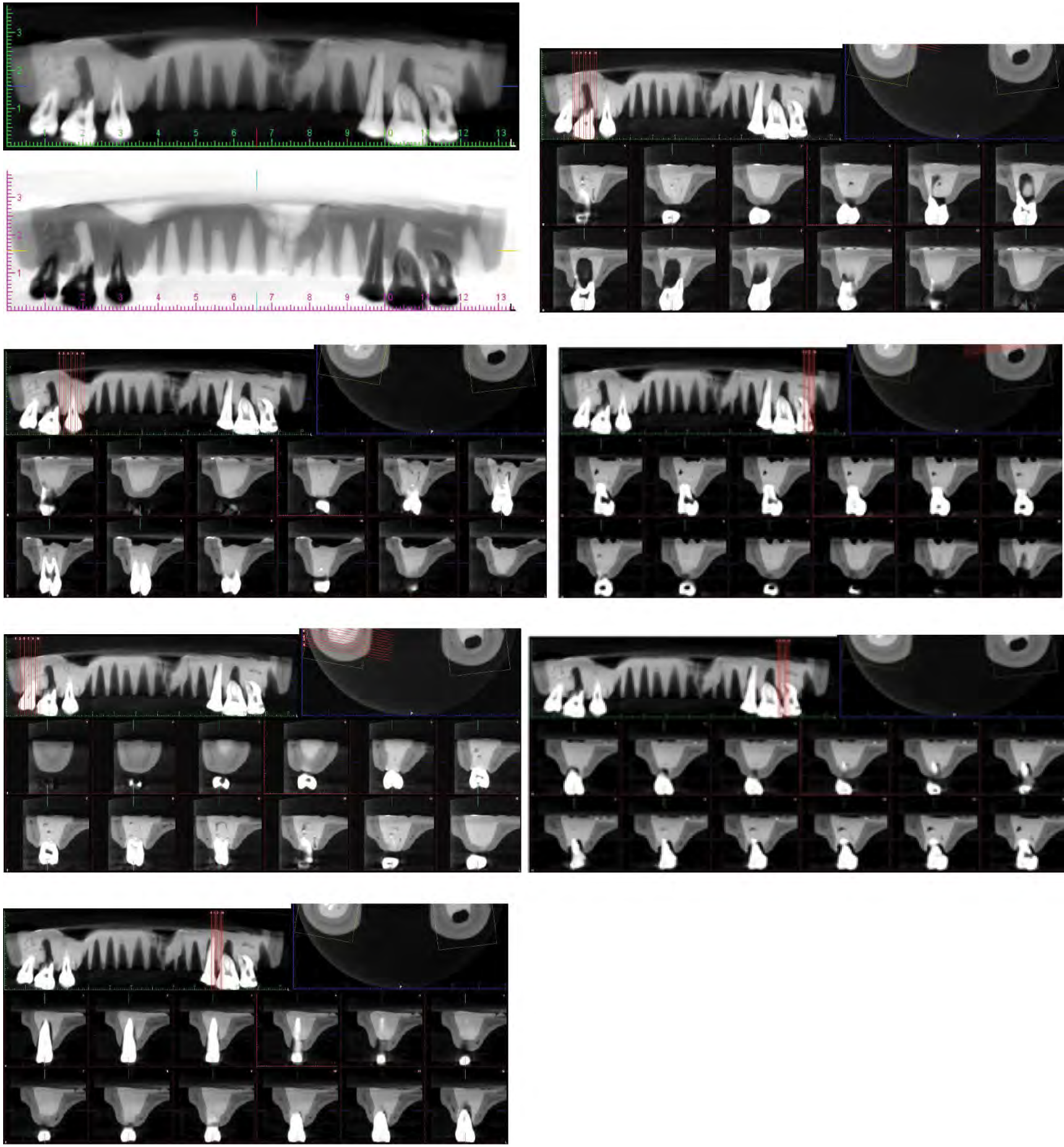

FIGURA 15. CBCT proximal

fapt, mai multe studii au arătat că între $25 \%$ şi $42 \%$ dintre leziunile carioase rămân nedetectate prin examinarea clinică efectuată fără examinare radiografică $(10,11)$. Evaluarea clinică pentru diagnosticarea leziunilor carioase incipiente sau de demineralizare trebuie asociată cu alte mijloace complementare, de regulă cu examenul radiologic.

Radiografiile sunt în general recomandate pentru detectarea leziunilor carioase proximale, iar printre acestea, radiografiile bitewing au devenit cea mai frecventă examinare radiologică intraorală (12).

Conform unor rapoarte din literatură, 25-40\% dintre leziunile cariei proximale nu pot fi detectate prin examinare clinică fără evaluare radiologică. Această situaţie evidenţiază importanţa diagnosticului acestor două examinări, care nu trebuie niciodată separate (13). 

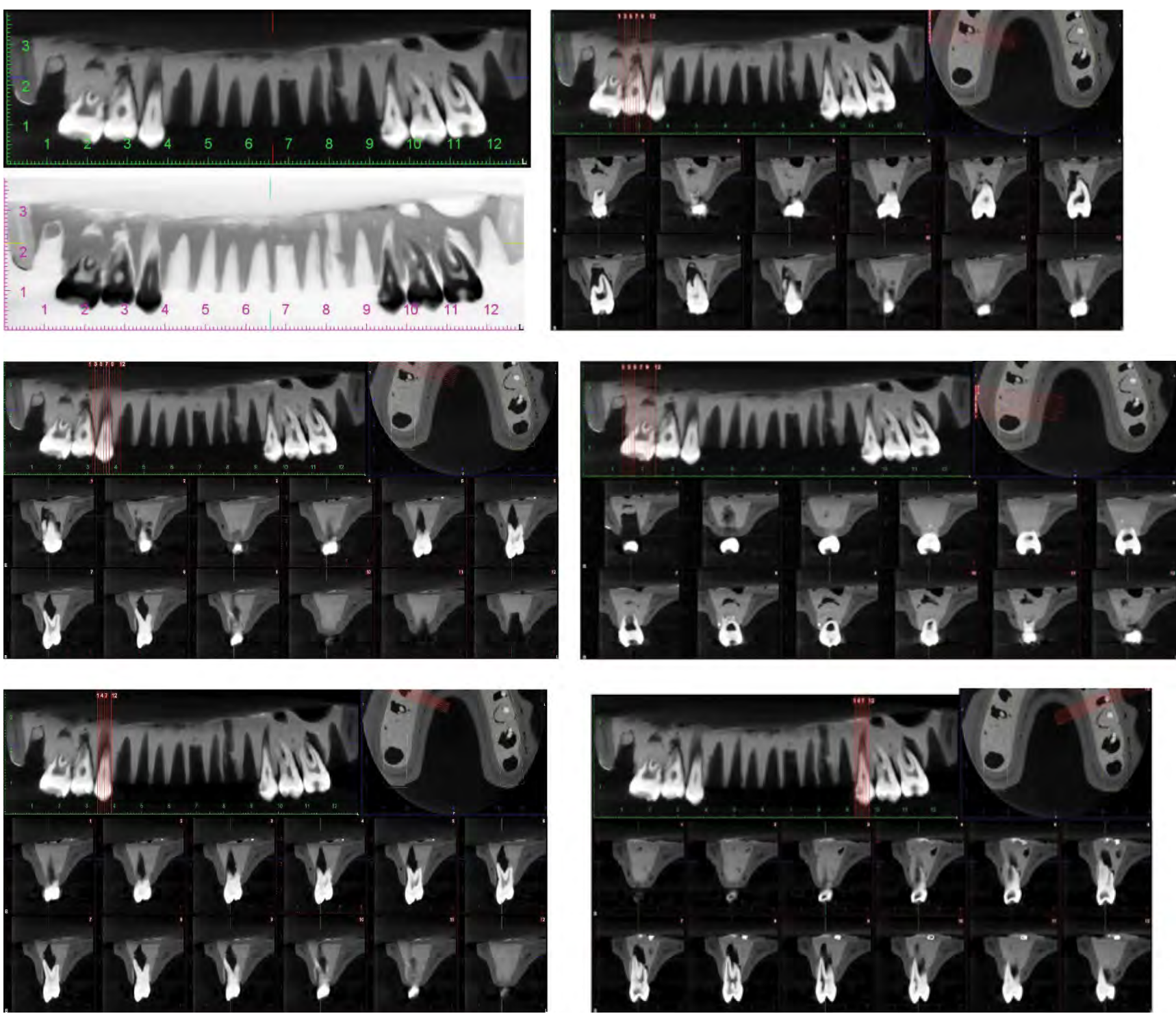

FIGURA 16. CBCT ocluzal

Acest studiu analizează capacitatea de a recunoaşte în RxRA, RxBW şi CBCT a proceselor de demineralizare, cariile incipiente în smalţ şi caria în dentină, situate proximal şi ocluzal, de către mai multe categorii de practicieni (cu şi fără experienţă).

Rata de detecţie radiografică a cariilor proximale este departe de a fi ideală, deoarece radiografiile bitewing standard detectează doar aproximativ $60 \%$ dintre leziunile proximale (14).

În studiul meu, la radiografia retroalveolară, la nivel proximal, 49\% dintre repondenţi nu au diagnosticat demineralizare, $42 \%$ caria în smalţ şi $16 \%$ caria în dentină.

La nivel ocluzal, $88 \%$ dintre repondenţi nu au diagnosticat demineralizarea, $60 \%$ caria în smalţ, toţi repondenţii au diagnosticat caria în dentină.
Studiul lui Hernandez J.A. et al. (2017) arată că $61,29 \%$ dintre interpretările $\mathrm{Rx}$ au fost clasificate radiologic eronat ca fără carie (15).

Aceste rezultate sunt de acord cu studiul efectuat de Bertella et al. în anul 2012, care a analizat $\mathrm{Rx}$ procese carioase incipiente (smalţ), constatând că $67,4 \%$ dintre aceste leziuni nu au prezentat radiotransparenţă radiologică (16).

RxBW arată că în zona proximală $74 \%$ dintre repondenţi cataloghează demineralizările şi cariile în smalţ drept dinţi indemni, iar la nivel ocluzal 90\% dintre repondenţi nu au diagnosticat demineralizare, iar $26 \%$ caria în smalţ.

Utilizarea radiografiilor bitewing pentru diagnosticarea cariilor ocluzale a fost pusă sub semnul întrebării, deoarece acestea au fost considerate mai utile pentru leziunile interproximale. $\mathrm{Cu}$ toate 
DEMINERALIZARE PROXIMAL
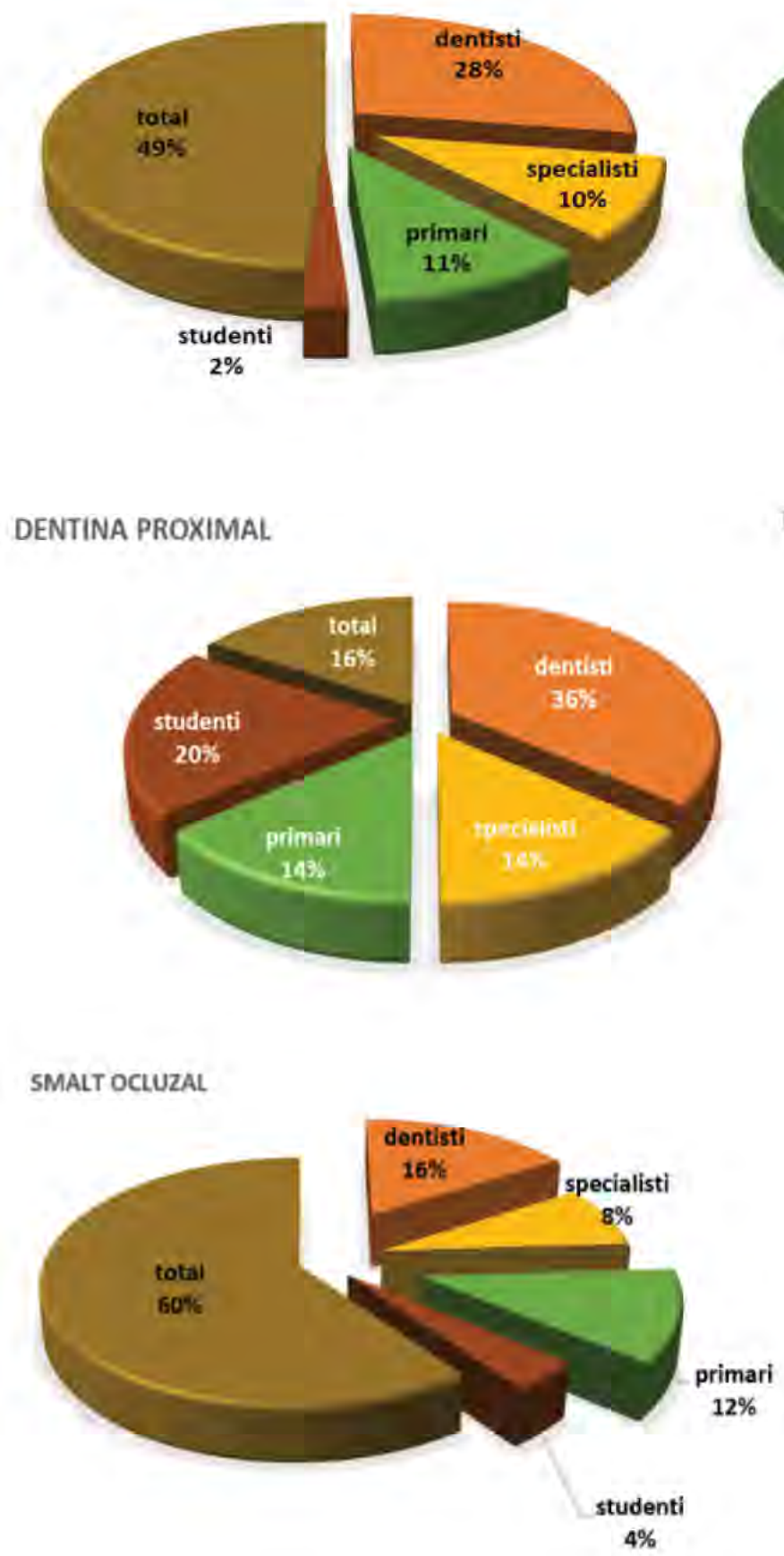

FIGURA 17. Rx retroalveolară

acestea, studiul realizat de Ricketts et al. a constatat că RxBW sunt mai senzitive decât examinarea vizuală pentru diagnosticarea cariilor ocluzale. Totuşi, utilizarea RxBW pentru a diagnostica leziunile carioase ocluzale ar trebui considerată ca o completare a diagnosticului vizual ) (10).

CBCT arată procentul cel mai mic de (72\% zonă proximală, $38 \%$ zonă ocluzală) de dinţi indemni, dar, totuşi, diferenţa nu este prea mare, probabil din

\section{SMALT PROXIMAL}
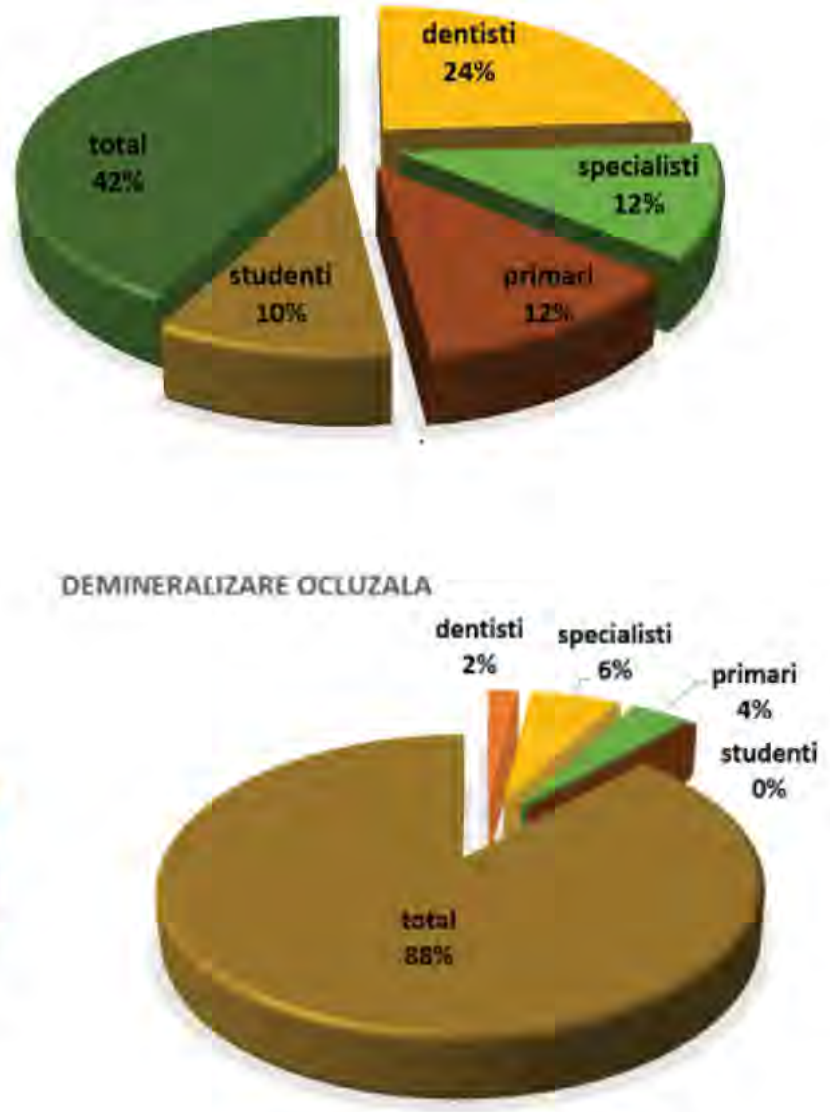

DENTINA OCLUZAL

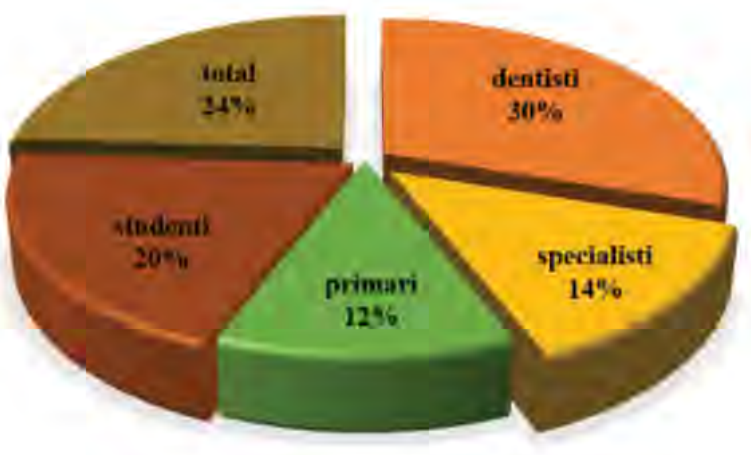

cauza utilizării sale limitate şi lipsa informaţiilor de interpretare a majorităţii repondenţilor.

Multe studii arată că ratele de detecţie a cariilor prin CBCT sunt aproximativ echivalente cu modalitătile intraorale $(17,18)$.

$\mathrm{O}$ actualizare recentă a literaturii arată că CBCT este echivalent cu tehnicile Rx intraorale în detectarea cariilor; structura dentară densă (smalţul), doza crescută de radiaţii, costul, timpul prelungit 
DEMINERALIZARE PROXIMAL
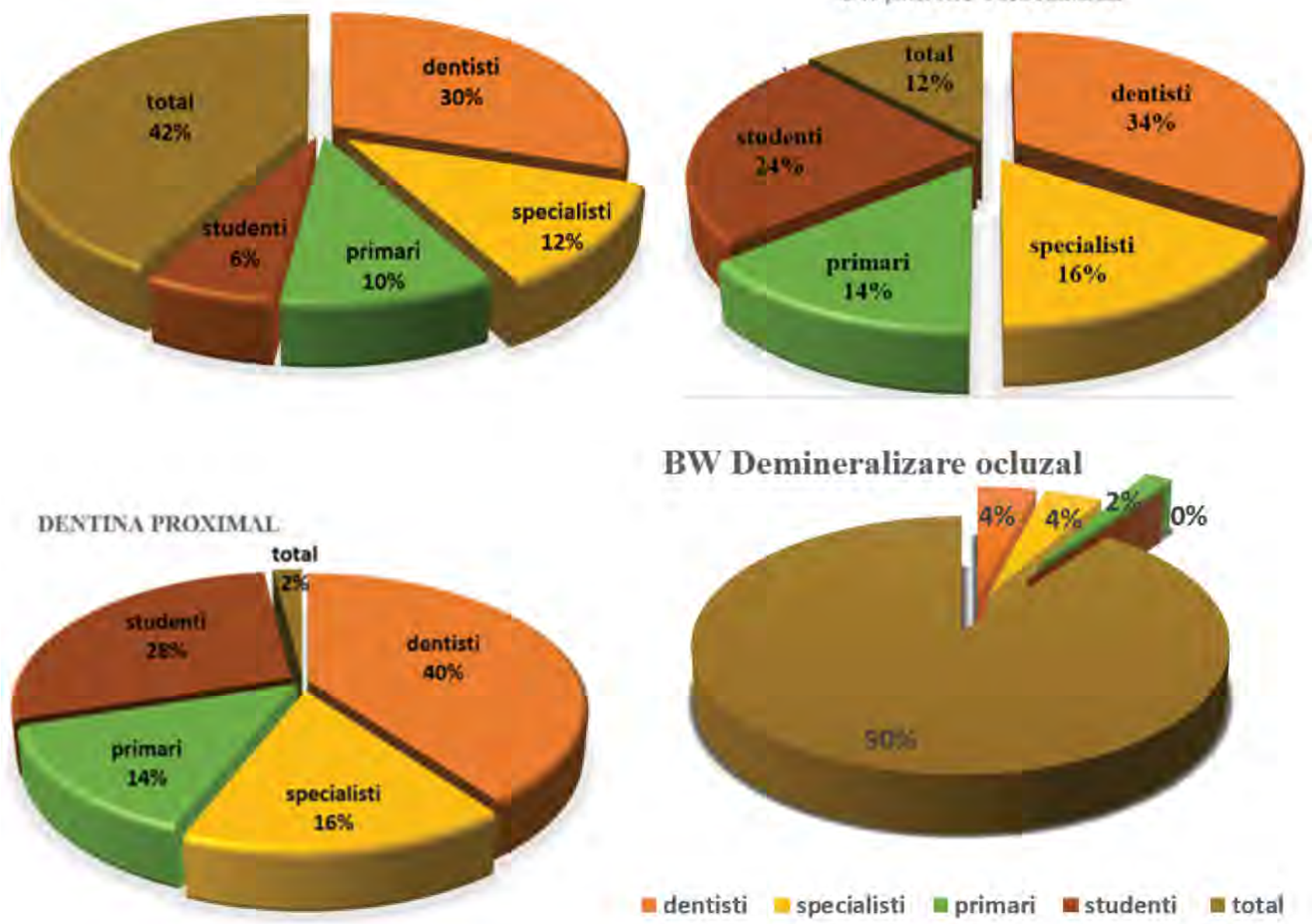

BW SMALT OCLUZAL

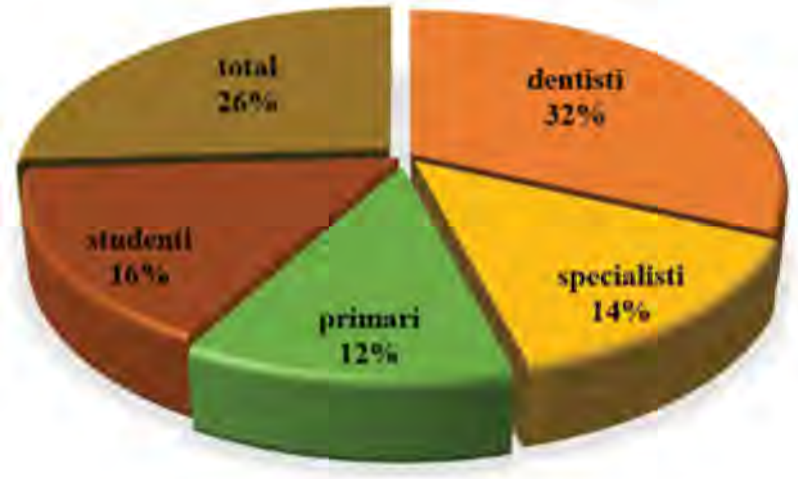

FIGURA 18. Rx Bitewing

sunt factori limitativi care fac că radiografiile bitewing să reprezinte modalitatea preferată de detectare a cariilor proximale (19).

Un studiu recent care a realizat un review referitor la utilizarea CBCT-ului în detectarea cariilor dentare a arătat că, la nivel proximal, mai mult de jumătate dintre articole au arătat eficacitatea CBCT

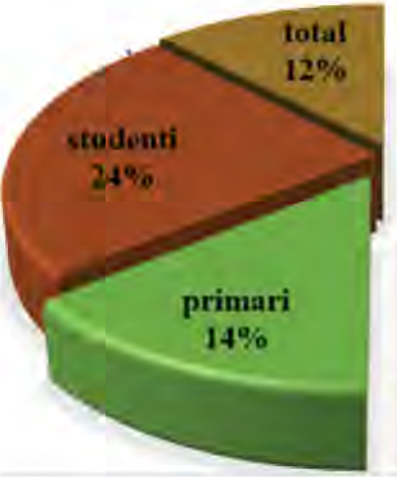

BW Demineralizare ocluzal

\section{BW SMALT PROXIMAL}

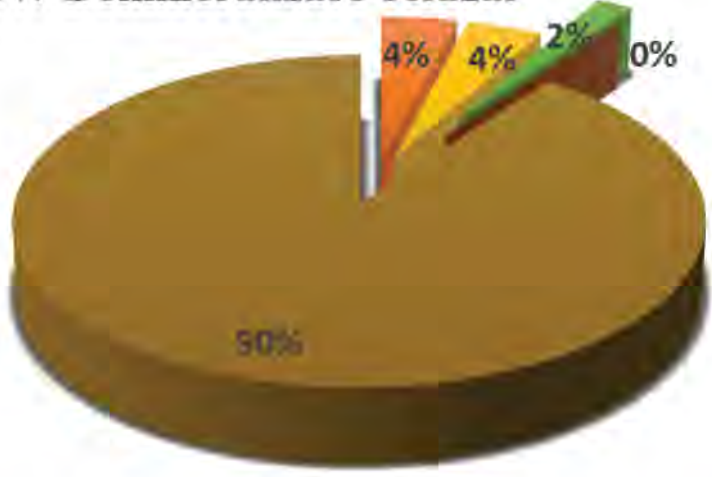

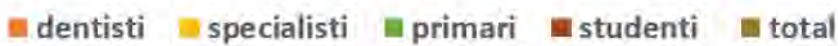

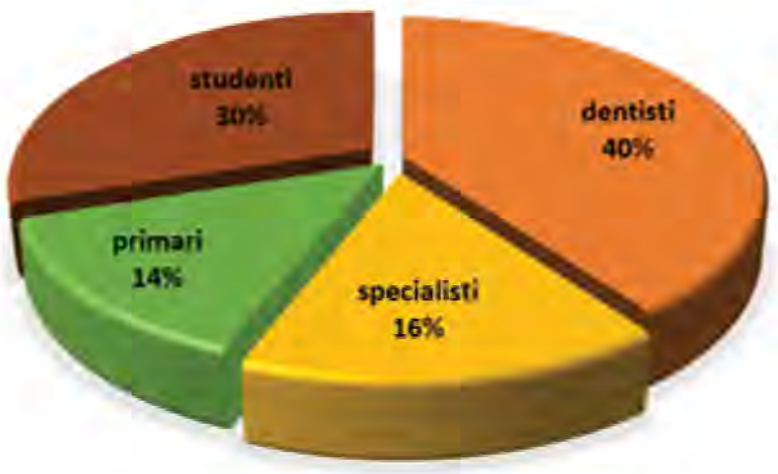

în detectarea cariei proximale, dar cu menţiunea că nu există o diferenţă semnificativă între CBCT şi radiografia $2 \mathrm{D}(20,21)$.

Unii dintre ei au declarat că CBCT are o eficacitate superioară (22), în timp ce Krzyżostaniak et al. (2015) (23) au constatat că CBCT are o eficacitate inferioară tehnicilor convenţionale. 
DEMINERALIZARE PROXIMAL

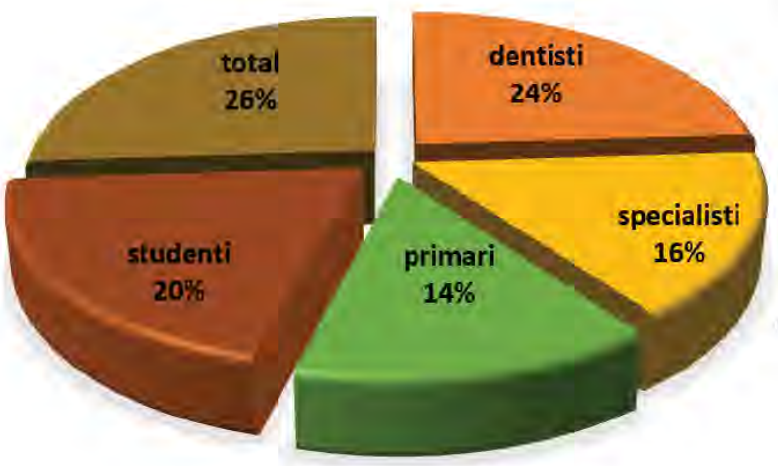

DENTINA PROXIMAL

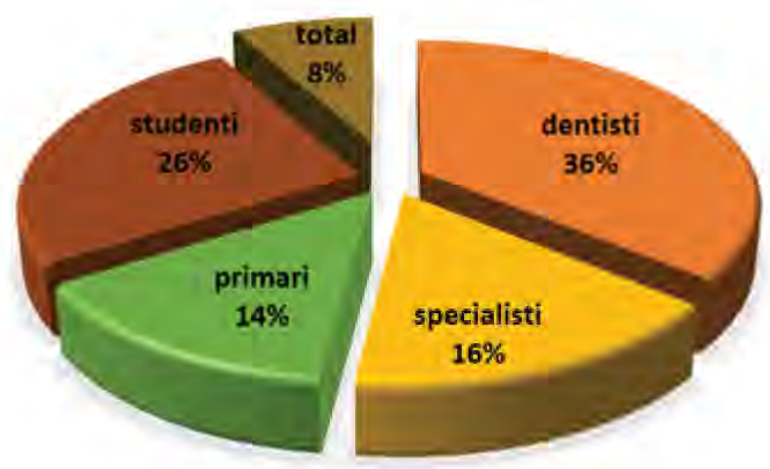

DENTINA OCLUZAL
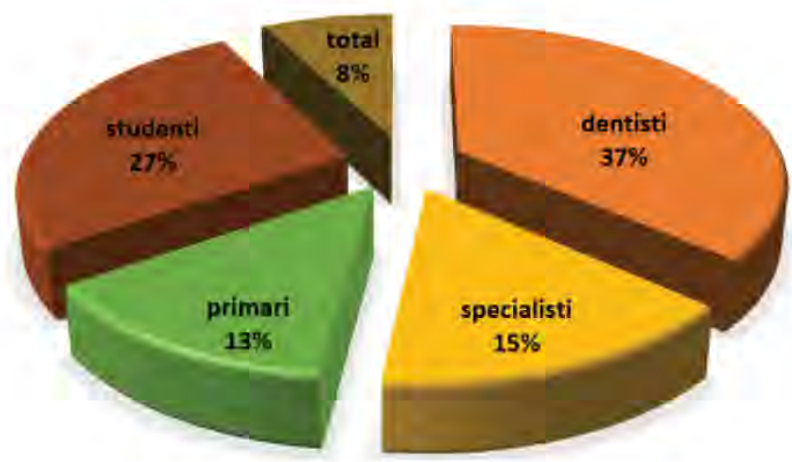

FIGURA 19. $C B C T$

În cazul cariilor ocluzale, s-a constatat o omogenitate de rezultate care acceptă că eficacitatea sistemelor CBCT a fost superioară metodelor convenţionale de detectare a cariilor (24), în timp ce doar Krzyżostaniak et al. (2015) (23) au menţionat că nu există nicio diferenţă semnificativă.

Conform unor cercetători, CBCT este excelentă pentru detectarea leziunilor carioase proximale (16).

\section{SMALT PROXIMAL}

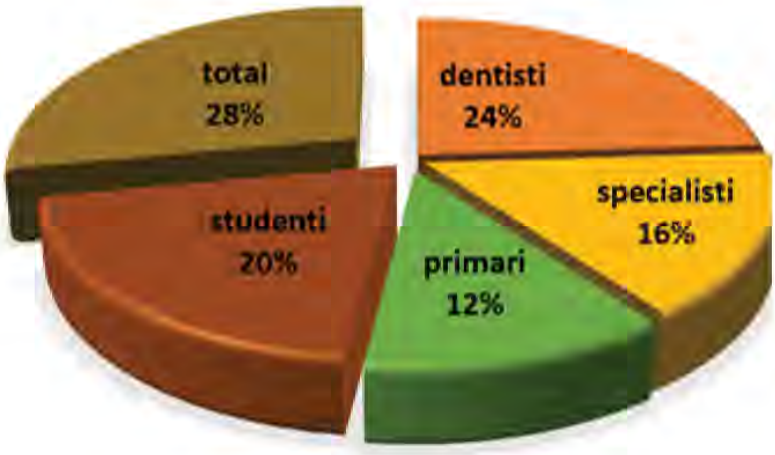

DEMINERALIZARE OCLUZAI.

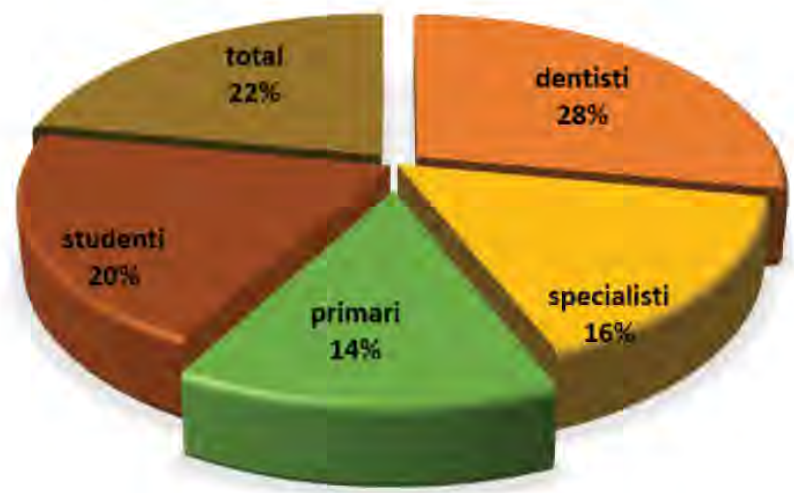

SMALT OCLUZAL

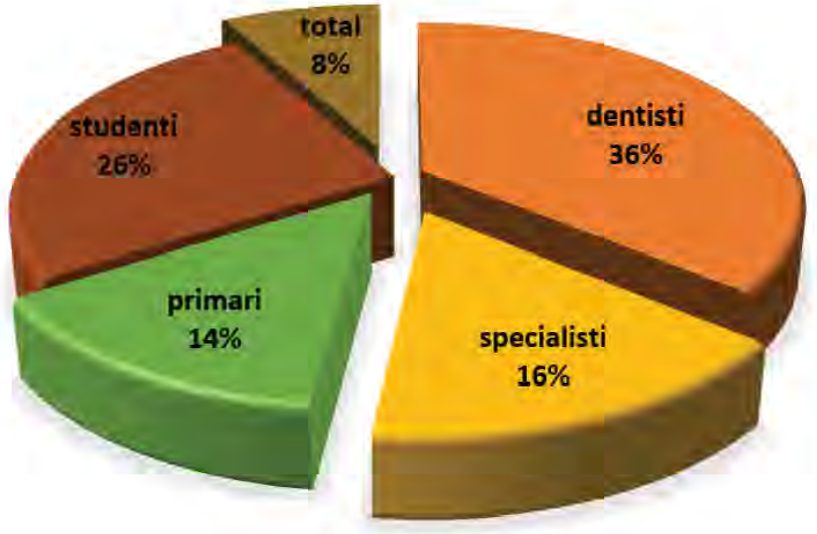

\section{CONCLUZII}

1. În urma examinărilor radiologice realizate în acest studiu, putem spune că detectarea cariei dentare este diagnosticată cel mai repede şi corect atunci când interesează ambele suprafeţe analizate, proximală şi ocluzală, cu evoluţie în stratul dentinar.

2. Majoritatea repondenţilor nu au recunoscut remineralizarea în smalţ atât pe suprafaţa ocluzală, cât şi proximală. 
3. De asemenea, valoarea reală a examenului radiologic este confirmată. Deşi se observă o detectare a leziunilor carioase incipiente mai bună în cazul RxBW decât în cazul Rx retroalveolară, totuşi, se constată că diferenţele nu sunt mari. De asemenea, creşte numărul leziunilor carioase detectate odată cu adâncimea lor.

\section{BIBLIOGRAFIE}

1. Sonya T. Mitchell ST et al. Satisfaction with dental care among patients who receive invasive or non-invasive treatment for non-cavitated early dental caries: findings from one region of the National Dental PBRN. BMC Oral Health. 2017;17:70. doi: 10.1186/ s12903-017-0363-8.

2. Haiter-Neto F, Wenzel A, Gotfredsen E. Diagnostic accuracy of cone beam computed tomography scans compared with intraoral image modalities for detection of caries lesions. Dentomaxillofac Radiol 2008;37:18-22.

3. Akdeniz BG, Grondahl HG, Magnusson B. Accuracy of proximal caries depth measurements: comparison between limited cone beam computed tomography, storage phosphor and film radiography. Caries Res 2006;40:202-7.

4. Young SM, Lee JT, Hodges RJ, Chang TL, Elashoff DA, White SC. A comparative study of high-resolution cone beam computed tomography and charge-coupled device sensors for detecting caries. Dentomaxillofac Radiol 2009;38:445-51.

5. Qu X, Li G, Zhang Z, Ma X. Detection accuracy of in vitro approximal caries by cone beam computed tomography images. Eur J Radiol (in press).

6. Kamburoglu K, Murat S, Yüksel SP, Cebeci AR, Paksoy CS. Occlusal caries detection by using a cone-beam CT with different voxel resolutions and a digital intraoral sensor. Oral Surg Oral Med Oral Pathol Oral Radiol Endod 2010;109:e63-9.

7. Kayipmaz S, Sezgin OS, Saricaoglu ST, Can G. An in vitro comparison of diagnostic abilities of conventional radiography, storage phosphor, and cone beam computed tomography to determine occlusal and approximal caries. Eur J Radiol (in press).

8. Young-Seok Park et al. Current status of dental caries diagnosis using cone beam computed tomography. Imaging Science in Dentistry 2011;41:43-51.

9. Bader JD, Shugars DA. A systematic review of the performance of a laser fluorescence device for detecting caries. J Am Dent Assoc 2004;135:1413-26.

10. Haak R, Wicht MJ, Noack MJ. Conventional, digital and contrast enhanced bite-wing radiographs in the decision to restore proximal carious lesions. Caries Res 2001;35:193-9.

11. Tam LE, McComb D. Diagnosis of occlusal caries: Part II. Recent diagnostic technologies. J Can Dent Assoc 2001;67:459-63.

12. Peker I, Toraman Alkurt M, Altunkaynak B. Film tomography compared with film and digital bitewing radiography for proximal caries detection. Dentomaxillofac Radiol. 2007Dec;36(8):495-9.

13. Baltacioglu IH et al. Comparison of diagnostic methods for early interproximal caries detection with near-infrared light transillumination: an in vivo study. BMC Oral Health. 2017;17:130.
4. CBCT este o investigaţie neuzuală pentru detectarea cariei dentare, clinicienii nu au exerciţiul interpretării.

\section{Mențiune}

Toţi autorii au contribuţie egală în realizarea acestui articol.

14. Bader JD, Shugars DA, Bonito AJ. Systematic reviews of selected dental caries diagnostic and management methods. J Dent Educ. 2001 Oct; 65(10):960-8.

15. Hernandez JA et al. Correlation of clinical and radiographic diagnosis of carious lesions in posterior teeth. Rev Fac Odontol Univ Antioq vol.28 no.2 Medellín Jan./June 2017.

16. Bertella N, Moura dos S, Alves LS, Damé-Teixeira N, Fontanella V, Maltz M. Clinical and radiographic diagnosis of underlying dark shadow from dentin (ICDAS 4) in permanent molars. Caries Res, 2013:47(5):429-432.

17. Senel B, Kamburoglu K, Uçok O, Yüksel SP, Ozen T, Avsever H. Diagnostic accuracy of different imaging modalities in detection of proximal caries. Dentomaxillofac Radiol. 2010 Dec;39(8):501-11.

18. Wenzel A, Hirsch E, Christensen J, Matzen LH, Scaf G, Frydenberg M. Detection of cavitated approximal surfaces using cone beam CT and intraoral receptors. Dentomaxillofac Radiol 2013;42:39458105.

19. Wenzel A. Radiographic display of carious lesions and cavitation in approximal surfaces: Advantages and drawbacks of conventional and advanced modalities. Acta Odontol Scand. 2014 May; 72(4):251-64.

20. Kayipmaz S, Sezgin ÖS, Saricaoğlu ST, Çan G. An in vitro comparison of diagnostic abilities of conventional radiography, storage phosphor, and cone beam computed tomography to determine occlusal and approximal caries. Eur J Radiol. 2011 Nov; 80(2):478-82. 37.

21. Valizadeh S, Tavakkoli MA, Karimi Vasigh H, Azizi Z, Zarrabian T. Evaluation of Cone Beam Computed Tomography (CBCT) System: Comparison withIntraoral PeriapicalRadiography in Proximal Caries Detection. J Dent Res Dent Clin Dent Prospects. 2012;6:1-5.

22. Wenzel A, Hirsch E, Christensen J, Matzen LH, Scaf G, Frydenberg M. Detection of cavitated approximal surfaces using cone beam CT and intraoral receptors. Dentomaxillofac Radiol. 2013; 42(1):39458105.

23. Shahidi S, Zadeh NK, Sharafeddin F, Shahab S, Bahrampour E, Hamedani S An in vitro comparison of diagnostic accuracy of cone beam computed tomography and phosphor storage plateto detect simulated occlusal secondary caries under amalgam restoration. Dent Res J (Isfahan). 2015;12:161-6.

24. Krzyżostaniak J, Kulczyk T, Czarnecka B, Surdacka A. Comparative study of the diagnostic accuracy of cone beam computed tomography and intraoral radiographic modalities for the detection of noncavitated caries. Clin Oral Investig. 2015;19:667-72. 